Check for updates

The BMJ

Cite this as: BMJ 2020;370:m3798 http://dx.doi.org/10.1136/bmj.m3798 Published: 30 September 2020

\section{Covid-19: Politicians must be honest about what NHS can deliver during pandemic, say leaders}

\author{
Gareth lacobucci
}

NHS leaders have called for an honest assessment of what the health service can deliver as it grapples with a "triple whammy" of rising covid-19 infections, a major backlog of treatment, and reduced capacity due to infection control measures.

In a report published this week the NHS Confederation, which represents organisations throughout the healthcare sector, says that the service is at "a critical crossroads" as winter approaches. ${ }^{1}$ The report, which surveyed more than 250 senior leaders in the English NHS, calls on politicians to be realistic with the public about the impact of covid-19 on waiting times and other areas of treatment.

Speaking at a webinar to discuss the report, Niall Dickson, the confederation's outgoing chief executive, said that, while the NHS had made "fantastic strides" to resuming routine services, the pandemic's impact on capacity was "likely to go on for several years."

"The service needs government investment to support new ways of working that will enable it to safely restore services, and understanding from the public, while it adjusts to this big backlog of patients needing care," he said. "Political leaders [need] to help manage expectations about what is possible."

\section{Local control}

The report urges the government to make extra investment to enable the NHS to emerge from the pandemic on a stronger footing.

Some $88 \%$ of NHS leaders surveyed for the report said that a lack of funding would be a significant barrier to delivering waiting time standards for patients, and $74 \%$ were not confident that their services would be able to meet the national targets to bring back routine operations to "near normal" levels by the end of October.

Only $8 \%$ said that their current funding allowed them to deliver safe and effective services. And nine in 10 (90\%) were concerned about the long term impact of the pandemic on doctors, nurses, and other frontline staff.

More broadly, the report calls for ongoing work on integrating services to continue and for changes that were introduced in the wake of the pandemic-including stripping back bureaucracy and handing more control to local NHS leaders-to be retained permanently.

The government must also take "sustained and funded action" to tackle the health inequalities that have been exacerbated by covid-19, it adds.

More than eight in 10 leaders surveyed (84\%) said that the NHS must deliver a step change in how it cares for diverse and marginalised communities.

Victor Adebowale, chair of the NHS Confederation, said, “This is the moment for the government to grasp the nettle, be bold, and invest in a health and care system not just for this winter but for the long term.

"Above all, we need to see a radical and conscious shift in every part of the country towards tackling health inequalities. If there is one lesson from the pandemic, it is that our universal health service does not care for everyone equally."

Claridge F, Deighton R, Pett W. NHS reset: a new direction for health and care. NHS Confederation. Sep 2020. https://www.nhsconfed.org/-/media/Confederation/Files/Publications/Documents/NHS-Reset-a-new-direction-for-health-and-care.pdf.

This article is made freely available for use in accordance with BMJ's website terms and conditions for the duration of the covid-19 pandemic or until otherwise determined by BMJ. You may use, download and print the article for any lawful, non-commercial purpose (including text and data mining) provided that all copyright notices and trade marks are retained. 